\title{
Future time perspective and turnover intention: The mediating role of resilience
}

\author{
Dyah Triarini Indirasari, ${ }^{1}$ Debora Eflina Purba, ${ }^{2}$ Rizka Anindita ${ }^{3}$ \\ 1, 2, ${ }^{3}$ Faculty of Psychology, Universitas Indonesia, Depok - Indonesia
}

\begin{abstract}
The intention of employees to leave the organization, or known as turnover intention, is something that must be taken seriously by an organization as it may affect the sustainability of the organization. This study aimed to determine the effect of resilience as a mediator in the relationship between future time perspective (FTP) and turnover intention. Data were taken using convenience sampling from various state-owned enterprises (Badan Usaha Milik Negara, BUMN) in Depok and Jakarta area $(\mathrm{N}=310)$. The study used a self-rating method using 3 measurements, namely Zimbardo Time Perspective Inventory, Brief Resilience Scale, and Turnover Intention. Data were analyzed using mediation technique by Hayes' PROCESS macro on SPSS program. The results showed that FTP negatively and significantly affected turnover intention and that resilience fully mediated the relationship. As a practical implication, this study provides information for organizations to employ programs to increase employees' future time perspective and resilience.
\end{abstract}

Keywords: future time perspective; resilience; turnover intention; Zimbardo Time Perspective Inventory

\begin{abstract}
Abstrak: Intensi karyawan untuk meninggalkan organisasi (turnover intention) merupakan hal yang perlu diperhatikan dengan sungguh-sungguh oleh suatu organisasi karena dapat memengaruhi keberlanjutan suatu organisasi. Penelitian ini bertujuan untuk mengetahui pengaruh resiliensi sebagai variabel mediator pada hubungan future time perspective (FTP) dan intensi meninggalkan organisasi. Responden dalam penelitian ini adalah 310 karyawan yang diambil secara convenient dari berbagai Badan Usaha Milik Negara (BUMN) di wilayah Depok dan Jakarta. Penelitian menggunakan metode self-rating dari 3 alat ukur, yakni Zimbardo Time Perspective Inventory, Brief Resilience Scale, dan Turnover Intention. Pengolahan data dilakukan dengan menggunakan teknik analisis mediasi pada makro PROCESS yang dikembangkan oleh Hayes untuk program SPSS. Hasil penelitian menunjukkan bahwa FTP berpengaruh secara negatif dan signifikan pada intensi karyawan untuk meninggalkan organisasi. Data juga menunjukkan bahwa resiliensi berperan sebagai mediator secara penuh pada hubungan antara FTP dan intensi meninggalkan organisasi. Sebagai implikasi praktis, hasil penelitian ini memberikan masukan kepada organisasi untuk membuat program intervensi yang dapat meningkatkan FTP dan resiliensi karyawan.
\end{abstract}

Kata Kunci: future time perspective; resiliensi, intensi meninggalkan organisasi; Zimbardo Time Perspective Inventory

Corresponding Author: Debora E. Purba (e-mail: eflina@ui.ac.id). Faculty of Psychology, Universitas Indonesia. Kampus Baru UI Depok, Indonesia 16424. 


\section{Introduction}

Every organization does not expect its potential and good performer employees to resign from their jobs. Resignation of an employee from an organization is known as turnover (Tett \& Meyer, 2006). The results of a survey by Michael Page Consulting showed that $72 \%$ of the total 500 respondents in different organizations in Indonesia stated that they wanted to resign from their organizations within a year ahead (Michael Page Consulting, 2015). This indicates that the tendency of employees to leave their jobs is relatively high and it poses a problem to which every organization must pay attention.

Previous studies showed some factors contributed to employee's turnover intention, namely the desire to increase their work experience, better compensation from other organization, and unfairness received from the workplace (Dilara Emiroğlu, Akova, \& Tanrıverdi, 2015; Kaur, Mohindru, \& Pankaj, 2013; Nadiri \& Tanova, 2010; Zopiatis, Constanti, \& Theocharous, 2014). These results show that the reasons for employees to quit from their current job can come from both internal and external factors. The current study is focused on the internal factors of employee turnover intention, namely future time perspective and resilience.

Turnover intention is defined by Tett \& Meyer (2006) as a deliberate intention of an employee to leave his/her organization. Before leaving the organization (actual turnover), the employee must have the intention (turnover intention), and it constitutes the strongest predictor of actual turnover (Joo \& Park, 2014; Kaur et al., 2013). Previous studies show that there is significant negative correlation between the variables of job satisfaction, job commitment, work engagement, and work quality, with intention to resign (Joo \& Park, 2014; Kaur et al,, 2013; Ncede, 2013).
Some consequences of high intention to leave an organization are, among others, the high rate of absence, negative verbal expression from employees, tendency to delay in doing task or coming late to office, and decrease in job satisfaction and commitment to organization (Joo \& Park, 2014; Ncede, 2013).

Regarding individual's internal factors, one of the variables that correlates negatively with the turnover intention is the so-called future time perspective (FTP) (Park \& Jung, 2015; Takahashi, Shimane, Ono, \& Hattori, 2013). It represents attitude toward goal setting and willingness to compromise present enjoyment for future consequences by delaying gratification (Zimbardo \& Boyd, 2015). A person with high future time perspective are characterized as having consideration of future consequences, controlled ego, and the tendency of not showing impulsiveness or doing any risk-taking behavior (Zimbardo \& Boyd, 2015).

Future time perspective itself is one of dimensions in the concept of time perspective, which is defined as an individual's tendency to divide personal and social experiences into some time frames in order to create order, coherence, and meaning on every occurrence (Zimbardo \& Boyd, 2015).

Zimbardo and Boyd (2015) categorized time perspective into five dimensions, namely pastnegative, past-positive, present-fatalistic, presenthedonistic, and future, in which every dimension has its own characteristics. Past-Negative individuals will show a tendency to remember negative experiences in the past, such as traumatic or unpleasant event. In contrast, a PastPositive individuals tend to remember past experiences as pleasant events. Individuals who high in Present-Fatalistic dimension tend to be submissive and helpless to things happening to 
them. Different characteristics are shown by individuals who are high in Present-Hedonistic, in which they are more oriented toward present enjoyment, impulsive and tend to show a sensation-seeking behavior. Lastly, individuals with Future perspective are more oriented toward the future and able to postpone the fulfillment of present desire in order to achieve more in the future. This type of individuals tends to show caution in their behaviors by considering everything before they take actions. According to Zimbardo and Boyd (2015). the high tendency towards one dimension of time perspective will affect individual's decision making, judgment, and behavior.

Studies on future time perspective and turnover intention have not shown the same results. The study conducted by Takahashi et al. (2013) revealed that future time perspective has significantly negative correlation with turnover intention. On the other hand, the study conducted by Park and Jung (2015) found that future time perspective and turnover intention have indirect correlation and mediated by other variables, namely commitment to career, commitment to organization, and occupational self-efficacy. This indicates that the correlation of both variables can be mediated by other psychological variables.

Further, Park and Jung (2015) explained that individuals with high levels of future time perspective appreciate their job even if the job is perceived to be difficult and tend to suppress their negative emotions when they think about the positive outcomes of their job. These characteristics, makes them work harder to develop their competencies in order to achieve goals. Hence, they have low intention to leave their organizations. The study by Bolotova and Hachaturova (2013) also showed that individuals with high levels of future time perspective are able to overcome problems in different situations moreover if the difficulties can increase better opportunities in their works in the future (Sims, Ruppel, \& Zeidler, 2016). Based on the results of these studies, future time perspective can be seen as one of characteristic that can improve individual's competence and confidence to face a problem. In other words, future time perspective can affect the resilience of an individual.

The study conducted by Bande, FernándezFerrín, Varela, and Jaramillo (2014) concluded that resilience is negatively correlated to turnover intention. Resilience itself is defined as an ability to overcome negative situation (Avey, Luthans, \& Jensen, 2009). Resilience can be perceived as a process of adaptation to overcome problems like trauma, difficulty, past tragedy, threat, or other condition that can generate stress, either from domestic, health, financial, or workplace problems (American Psychological Association, 2017). The results from previous studies also showed that individuals with high level of resilience in a workplace tend to show less withdrawal behavior although they experience difficulties in their job since they have positive emotions to overlook their difficulties (Avey et al., 2009; Bande et al., 2014). Factors that contribute to high resilience are, among others, social support, and high spirituality (Bukhori, Hassan, Hadjar, \& Hidayah, 2017). High resilience can help employees to respond to any problems or stress faced in their work environment.

In conclusion, individuals who have future time perspective tend to have high resilience in coping with problems in the workplace, and in turn decrease the intention to leave their organizations. Thus, we argue that resilience can serve as a mediaton variable between future time perspective and turnover intention.

To our knowledge, the number of studies that examine the correlation between future time perspective and turnover intention is still limited, 
whereas future time perspective is known as an individual variable that can have an effect on attitude and behavior of employee in the workplace. In addition, we argue that the present study contributes to the literature by advancing resilience as an underlying mechanism that explains the relationship between future time perspective and turnover intention. Thus, the objective of this study is to see more thoroughly the correlation between future time perspective and turnover intention that is mediated by resilience. The hypothesis proposed was that an individual high in future time perspective has low turnover intention in which the correlation of both is determined by the high level of resilience.

The relationship between future time perspective and turnover intention with the mediation of resilience can be explained based on the Conservation of Resources (COR) theory from Hobfoll (1989). The theory describes that resources in every individual such as character, energy, etc. affect how they react when being encountered with negative or threatening situations. If they encounter a problem, then they will try to defend and protect their valuable resources and to increase other resources in order avoid the negative situations such as threat, stress or pressure (Hobfoll, 1989).

An employee who high in future time perspective has a certain degree of optimism as one of their personal resources and will focus more on the goals he or she expects to achieve. Therefore, even in the face of problems or negative situations in the workplace, an individual with high level of future time perspective is able to focus on their future goals by overcoming the problems or negative situations because they are able to bounce back and be resilient, and in turn decrease the intention to leave the organization. The study conducted by Deery, Iverson, and Walsh (2010) also showed that in the context of organization, when employees lack of personal resources, their intention to leave the organization will be high.

Based on the above explanation, then, resilience and future time perspective can contribute as personal resources used to overcome stress from negative condition in the workplace, such as pressure and workload. Individuals high in future time perspective tend to have high resilience so that work pressure and workload will be regarded as challenges that must be faced, not as an opportunity to leave the organization.

This study focused on the role of resilience as a mediator in the correlation between future time perspective and turnover intention. The aim of this study was to prove that resilience can play the role as psychological mechanism that explains why an individual with higher degree of future time perspective tend to have a low turnover intention based on the theory of Conservation of Resources (Hobfoll, 1989).

\section{Method}

This study used a cross-sectional design in which the entire data are obtained in a one-time data collection. The respondents of this study were employees who had worked for at least a year in state-owned enterprises situated in Jakarta and Depok. They were chosen as the sites of the study because, if compared with private companies, state-owned company's organizational culture is more rigid and bureaucratic, which leads to have more complicated career path for its employees. Also, individuals who willing to work for state-owned companies usually because of the assurance of pension and job security which are higher than that in private companies. Data collection was done conveniently using online survey by sending a survey link to employees of several state-owned companies. 
The participants were also asked to share the link to their fellow workers.

Total respondents of this study are 328 respondents, but only 310 data could be processed because there are some missing data on the other 18 respondents (response rate $=94 \%$ ). The age of the respondents ranged from 20 to 56 years old $(M=30.74$ years old; $S D=9.32)$, which comprises of 184 male respondents (59\%), and 121 female (39\%) respondents, and 5 not mentioning their genders (2\%). Their educational background ranged from high school to doctoral degree, most of whom had bachelor's degree (228 people or $73 \%$ ).

Three scales were used in this study, which are resilience scale, future time perspective scale, and turnover intention scale. Each of the measurement was adapted to bahasa Indonesia. The process of adaptation was done using translationback translation procedure. The original English version was translated into Bahasa Indonesia, and then, the Indonesian version was translated back to English. After going through readability test and expert judgment, the psychometric test of all of the measurements were conducted.

The resilience scale was adapted from the Brief Resilience Scale by Smith et al. (2008). It consists of 6 items using a 5-point Likert scale ( $1=$ very much disagree to $5=$ very much agree). The internal consistency of the items was at the range of $0.198-0.583$. One item with 0.198 corrected item-total correlation value was eliminated because it was below the acceptable value of validity, which is 0.3 (Field, 2013). After eliminating 1 item, the result of reliability test showed Cronbach's alpha coefficient was 0.7. The internal consistency between the items also showed good validity, ranging from $0.32-0.64$. Item examples were "I experience difficulty in passing through stressing events in my life" and "I tend to require longer time to overcome obstacle in my life".

The second measurement, Future Time Perspective scale, was adapted from Zimbardo Time Perspective Inventory (ZTPI) by Zimbardo and Boyd (2015). This scale consists of 56 items with a 5-point Likert scale (1=very much disagree to $5=$ very much agree). There are 5 dimensions measured, namely past-negative, past-positive, present fatalistic, present-hedonistic, and future. The items used to measure future time perspective dimension are those belonging to future dimension, which consists of 13 items. Reliability test of the future time perspective scale showed the value of internal consistency between the items ranged between $0.11-0.49$. After eliminating 3 items with internal consistency value below 0.2 , the value of Cronbach's alpha gained was 0.73 . Item examples were "I believe that someone must plan his/her day every morning", and "Before making decision, I consider the possible loss and the benefit possibly gained".

The Turnover Intention scale used in this study was adapted from Turnover Intention formulated by Mobley, Horner, and Hollingsworth (1978). It consists of three items scored using a 5point Likert scale $(1=$ very much disagree to $5=$ very much agree). The three items have internal consistency value ranging from $0.71-0.79$ with the value of Cronbach's alpha was 0.86. Item examples were "I always think about how to get out of this organization", and "I actively look for any alternative workplace".

Data processing was done using descriptive analysis and hierarchical multiple regression analysis with SPSS. Regression analysis with bootstrapping from Hayes was used to test the hypothesis. 


\section{Results}

Table 1 shows that the correlation between future time perspective and turnover intention was not significant $(r=$ $.08, p=.136)$. It means that individuals who scored high in the future time perspective do not always have low score on turnover intention. Correlation between future time perspective and resilience showed a positive and significant correlation $(r=.37, p<0.01)$, meaning that individuals who have a higher score in future time perspective, will also high in their resilience. The correlation between resilience and turnover intention was apparently significant too $(r=-.29, p<$ 0.01 ), indicating that when individuals have good resilience, they tend to have low turnover intention.

Besides the three main variables, the researchers also analyzed demographic data (age, gender, and education). The result showed that age has a positive correlation with resilience $(r=$ .14, $p=.010$ ), meaning that the older is an individual, the stronger is his or her resilience. On the other hand, age has a negative correlation with turnover intention $(r=-.16, p=.005)$. It can be concluded that turnover intention will decrease as people get older. In the context of future time perspective, it is found that age did not have significant correlation with the variable $(r=$ $.06, p=.258$ ).

Based on gender, it was found that gender had negative correlation with resilience $(r=-.124$, $p=.030$ ), but positive with future time perspective $(r=-.118, p=.039)$. Male respondents had higher score of resilience and future time perspective than female. Gender also had positive correlation with turnover intention $(r=.180, p=$ .002), in which female participants tended to have higher score of turnover intention than male.

In order to test the proposed hypothesis, hierarchical multiple regression analysis was done using mediation analysis technique from Hayes (2013). The hypothesis of this study was whether resilience mediates the correlation between future time perspective and turnover intention. The result of the test can be seen on Table 2. Based on the data, future time perspective did not have direct correlation with turnover intention (total effect $=-.18, \mathrm{SE}=.12,95 \% \mathrm{CI}[-.42, .05]$ ), but the analysis of mediation model testing proved that resilience mediates the correlation between future time perspective and turnover intention (indirect effect $=-.24, \mathrm{SE}=.06,95 \%$ CI[-.36, -.12]). This type

Table 1.

Analysis of correlation between variables of the study

\begin{tabular}{|c|c|c|c|c|c|c|c|c|}
\hline \multicolumn{9}{|c|}{ Correlation } \\
\hline & Mean & SD & 1 & 2 & 3 & 4 & 5 & 6 \\
\hline 1. Age & 30.74 & 9.32 & 1 & & & & & \\
\hline 2. Gender & 1.39 & .49 & $-.17 * *$ & 1 & & & & \\
\hline 3. Education & 3.03 & .63 & $.14^{*}$ & -.00 & 1 & & & \\
\hline 4. Future Time Perspective & 3.91 & .44 & .06 & $-.11 *$ & .04 & 1 & & \\
\hline 5. Resilience & 3.56 & .63 & $.14^{*}$ & $-.12^{*}$ & .02 & $.37^{* *}$ & 1 & \\
\hline 6. Turnover intention & 2.24 & .95 & $-.16 * *$ & $.18^{* *}$ & .00 & -.08 & $-.29 * *$ & 1 \\
\hline
\end{tabular}

Note: $N=310 .{ }^{* *}$ significant on $p<0.01 .{ }^{*}$ significant on $p<0.05 . \mathrm{MO}=$ turnover intention. Age measured by year. Gender by code 1 = male, 2 = female. Education by code $1=$ high school, $2=3$-year vocational college, $3=$ Bachelor degree, 4 = master degree, 5 = doctoral degree 
of mediation is a full mediation. There is no direct effect because future time perspective and turnover intention have no significant correlation with each other, but there is indirect effect due to the role of resilience as mediator between both variables. Based on the hierarchical multiple regression analysis, it can be concluded that the alternative hypothesis of this study can be accepted.

Table 2 shows that the determination coefficient $\left(\mathrm{R}^{2}\right)$ gained was .08. It means that there was $8 \%$ of the alteration of turnover intention explained by future time perspective and resilience.

\section{Discussion}

The results of this study showed that the participants with future time perspective had good resilience, which decreased their turnover intention. This finding is consistent with the result of the study done by Park and Jung (2015), which concluded that the correlation between future time perspective and turnover intention is indirect as they are mediated by other variables such as commitment to career, commitment to organization, and occupational self-efficacy.

Overall, the result is supporting the Conservation of Resources (COR) theory composed by Hobfoll (1989). Future time perspective and resilience are resources that exist in individuals, so that when individuals face a difficult situation, threat, or pressure at workplace, their reactions to these threats will be influenced by the presence or absence of these resources. Individuals with higher future time perspective and resilience will be more able to deal with the problems or pressures they face. Therefore, employees with such attitudes can decrease their turnover intentions.

Several previous studies found a significant negative effect of resilience on turnover intention. For example, Avey et al. (2009) found that psychological capital, including resilience, had a negative and significant effect on turnover intention. They stated that psychological capital is the key variable for understanding negative variables, including turnover intention. On the other hand, Yu and Lee (2018) found that resilience acts as a mediator in the relationship between satisfaction in the work environment and turnover intention. Thus, it can be concluded that the correlation between resilience and turnover intention is relatively proximal, which resilience can be the mediator for turnover intention.

Table 2.

The model of resilience mediation in the correlation of future time perspective and turnover intention

\begin{tabular}{|c|c|c|c|c|c|c|c|c|c|}
\hline \multicolumn{9}{|c|}{ Outcome } & $\mathrm{Y}$ (Turnover Intention) \\
\hline Antecedent & & & Coeff. & $S E$ & $P$ & & Coeff. & $S E$ & $p$ \\
\hline \multirow[t]{2}{*}{ X (FTP) } & $a$ & & .52 & .07 & .00 & $C$ & -.18 & .12 & .13 \\
\hline & & & & & & $c^{\prime}$ & .05 & .12 & .65 \\
\hline M (Resilience) & & & - & - & - & B & -.45 & .08 & .00 \\
\hline Constant & & & $\begin{array}{c}1.51 \\
Q^{2}=.13 \\
08)=48\end{array}$ & $\begin{array}{l}.29 \\
p<0.05\end{array}$ & .00 & $i 2$ & $\begin{array}{c}3.64 \\
R^{2}=.08 \\
77)=14.2\end{array}$ & $\begin{array}{l}.48 \\
<0.0\end{array}$ & .00 \\
\hline
\end{tabular}

Note: Indirect effect $=-.24, \mathrm{SE}=.06,95 \% \mathrm{CI}[-.36,-.12] . \mathrm{C}=$ total effect. $\mathrm{C}^{\prime}=$ direct effect 
This study had different result from the study conducted by Takahashi et al. (2013) who found that future time perspective was negatively and significantly related to the turnover intention, but it was in line with Park and Jung's research (2015), which found a nonsignificant correlation between future time perspective and turnover intention. This is likely due to differences in the characteristic of the sample. The respondents of the study by Takahashi et al. (2013) were entrepreneurs, while those of Park and Jung's study (2015) were employees from various companies. Entrepreneurs are groups of people who consciously choose to run a business, so it is not easy for them to leave the business. Having a high future time perspective can provide them enough resource to stay in their businesses. Meanwhile, in the employee population, a high future time perspective does not mean being able to keep working at the same place, because it is easier for them to find other jobs compared to entrepreneurs.

In the scope of industry and organization, number of studies on time perspective is still limited, so this research contributes to the development of time perspective theory in organizations. Specifically, the practical implications of the results of this study for the division of Human Resources (HR) or Human Capital (HC). Time perspective and resilience can be used as parts of employee selection to see someone's endurance in facing severe situations at work. Trainings such as employee career planning or career track as part of future time perspective and training to increase resilience can help an employee to deal with obstacles faced at workplace and ultimately reduce the possibility of leaving the job. Executive coaching and emotional regulation training are also effective methods for establishing good resilience in employees, to reduce turnover intention (Grant, Curtayne, \&
Burton, 2009; Izzaturrohmah \& Khaerani, 2018). In terms of time perspective, the future time perspective dimension on employees can be developed with interventions in the form of the Time Perspective Modification Intervention that can improve future orientation or long-term orientation and optimism regarding the achievement of future goals (Ferrari, Nota, \& Soresi, 2012; Marko \& Savickas, 1998).

We realize there were some limitations in this study such as the use of a correlational research design which did not allow us to develop causal relations among the research variables. There is also a possibility that it is the nature of resilience that makes an individual's future time perspective increase, and not vice versa. Our belief in the model of this study was strengthened by the theoretical framework used. To find out if there is a causal relationship between the variables, a further study is needed. In addition, this study only focused on individual's internal factors, namely resilience and future time perspective in affecting turnover intention. Next study will be better if it overcomes the limitations of this study by using the theory of Cognitive-Affective Personality System (CAPS) from Mischel and Shoda (1995). This theory sees and understands an individual's behavior based on personality, the situation at hand, and the interaction of both.

The second limitation was that the sample of this study only covered state-owned organizations or enterprises situated in the Jakarta and Depok regions, so it could not be generalized to other types of organizations, such as private enterprises, start-ups, or multinational organizations. Moreover, the sample collected was not representative of state-owned companies in general, because we were only able to collect samples in Depok and Jakarta areas by convenience sampling method. Thus, it may reduce the possibility to make a generalization on the result of this study. 
The third limitation was that all data were taken using self-report, thereby it increased the likelihood of fatigue in filling out the questionnaire and also a possibility of common method bias. This limitation often occurs in collecting data at onetime and there is also a tendency for participants to fill out questionnaires based on their ideal answers, not what they actually feel (Podsakoff, MacKenzie, Lee, \& Podsakoff, 2003).

\section{Conclusion}

The conclusion of this study is that resilience fully mediated the relationship between future time perspective and turnover intention. Future time perspective and resilience have significant positive correlation, while resilience and turnover intention have significant negative correlation.

The result of this study is consistent with that of the study by Park and Jung (2015) which revealed that future time perspective and turnover intention do not have direct correlation but it is mediated by other variable. In this study, the mediating variable that can decrease the turnover intention is resilience.

\section{Recommendations}

Further research is suggested to differentiate state-owned enterprises into several categories, for example banking, non-banking, insurance, and so on. Respondents who work for non-banking SOEs and banking SOEs may have different work climates, so that the workload and stressors in each category are not the same. This, then, can have an impact on individual's resilience to face challenges and workloads (The Australian Psychological Society, 2011).

In addition, to avoid fatigue in participants in filling out the questionnaire, a temporal separation technique can be used, by collecting data of the predictor, mediator, and outcome variables at different times. Another method that can be done is by providing a different format of questionnaires between the predictor variable and the outcome variable, for example with a Likert scale and face scale or a short entry. These methods can also reduce the effect of common method biases (Podsakoff et al., 2003).[]

\section{References}

American Psychological Association. (2017). The road to resilience.

Avey, J. B., Luthans, F., \& Jensen, S. M. (2009). Psychological capital: A positive resource for combating employee stress and turnover. Human Resource Management, 48(5), 677-693. https://doi.org/10.1002/hrm.20294

Bande, B., Fernández-Ferrín, P., Varela, J. A., \& Jaramillo, F. (2014). Emotions and salesperson propensity to leave: The effects of emotional intelligence and resilience. Industrial Marketing Management. https://doi.org/10.1016/j.indmarman.2014.10.011

Bolotova, A. K., \& Hachaturova, M. R. (2013). The role of time perspective in coping behavior. Psychology in Russia: State of the Art, 6(3), 120-131. https://doi.org/10.11621/pir.2013.0311

Bukhori, B., Hassan, Z., Hadjar, I., \& Hidayah, R. (2017). The effect of sprituality and social support from the family toward final semester university students' resilience. Man in India, 97(19), 313-321.

Deery, S. J., Iverson, R. D., \& Walsh, J. T. (2010). Coping strategies in call centres: Work intensity and the role of co-workers and supervisors. British Journal of Industrial Relations, 48(1), 181-200. https://doi.org/10.1111/j.1467-8543.2009.00755.x 
Dilara Emiroğlu, B., Akova, O., \& Tanrıverdi, H. (2015). The relationship between turnover intention and demographic factors in hotel businesses: A study at five star hotels in Istanbul. In Procedia Social and Behavioral Sciences (Vol. 207, pp. 385-397). https://doi.org/ 10.1016/j.sbspro.2015.10.108

Ferrari, L., Nota, L., \& Soresi, S. (2012). Evaluation of an intervention to foster time perspective and career decidedness in a group of Italian adolescents. The Career Development Quarterly, 60(1), 82-96. https://doi.org/10.1002/j.2161-0045.2012.00007.x

Field, A. P. (2013). Discovering statistics using IBM SPSS statistics. SAGE.

Grant, A. M., Curtayne, L., \& Burton, G. (2009). Executive coaching enhances goal attainment, resilience and workplace well-being: A randomised controlled study. The Journal of Positive Psychology, 4(5), 396-407.https://doi.org/10.1080/17439760902992456

Hobfoll, S. F. (1989). Conservation of resources: A new attempt at conceptualizing stress. American Psychologist, 44(3), 513-524. https://doi.org/10.1037/0003-066X.44.3.513

Izzaturrohmah, \& Khaerani, N. M. (2018). Peningkatan resiliensi perempuan korban pelecehan seksual melalui pelatihan regulasi emosi. Psikohumaniora: Jurnal Penelitian Psikologi, 3(1), 117-140. https://dx.doi.org/10.21580/pjpp.v3i1.2527

Joo, B.-K., \& Park, S. (2014). Career satisfaction, organizational commitment, and turnover intention: The effects of goal orientation, organizational learning culture and developmental feedback. Leadership \& Organization Development Journal, 3, 482-500. https://doi.org/10.1108/ 01437731011069999

Kaur, B., Mohindru, \& Pankaj, D. (2013). Antecedents of turnover intentions: A literature review. Global Journal of Management and Business Studies, 3(10), 1219-1230. Retrieved from https://www.ripublication.com/gjmbs_spl/gjmbsv3n10_26.pdf

Marko, K. W., \& Savickas, M. L. (1998). Effectiveness of a career time perspective intervention. Journal of Vocational Behavior, 52(1), 106-119. https://doi.org/10.1006/jvbe.1996.1566

Michael Page Consulting. (2015). 2015 Employee Intentions Report - Indonesia. Retrieved from https://www.michaelpage.co.id/

Mischel, W., \& Shoda, Y. (1995). A cognitive-affective system theory of personality: Reconceptualizing situations, dispositions, dynamics, and invariance in personality structure. Psychological Review, 102(2), 246-268.

Mobley, W. H., Horner, S. O., \& Hollingsworth, A. T. (1978). An evaluation of precursors of hospital employee turnover. Journal of Applied Psychology, 63(4), 408-414. https://doi.org/ 10.1037/0021-9010.63.4.408

Nadiri, H., \& Tanova, C. (2010). An investigation of the role of justice in turnover intentions, job satisfaction, and organizational citizenship behavior in hospitality industry. International Journal of Hospitality Management, 29(1), 33-41. https://doi.org/10.1016/J.IJHM.2009.05.001

Ncede, N. (2013). Factors contributing to employee turnover intention at a selected company in the Cape Town clothing industry. Cape Peninsula University of Technology.

Park, I. J., \& Jung, H. (2015). Relationships among future time perspective, career and organizational commitment, occupational self-efficacy, and turnover intention. Social Behavior and Personality: An International Journal, 43(9), 1547-1561. https://doi.org/10.2224/ sbp.2015.43.9.1547 
Podsakoff, P. M., MacKenzie, S. B., Lee, J.-Y., \& Podsakoff, N. P. (2003). Common method biases in behavioral research: A critical review of the literature and recommended remedies. Journal of Applied Psychology, 88(5), 879-903. https://doi.org/10.1037/0021-9010.88.5.879

Sims, R. L., Ruppel, C. P., \& Zeidler, P. (2016). Work strain, job satisfaction, and intention to quit: The moderating effect of long-term orientation. International Journal of Stress Management, 23(1), 23-43. https://doi.org/10.1037/a0039755

Smith, B. W., Dalen, J., Wiggins, K., Tooley, E., Christopher, P., \& Bernard, J. (2008). The Brief Resilience Scale: Assessing the ability to bounce Back. International Journal of Behavioral Medicine, 15, 194-200. https://doi.org/10.1080/10705500802222972

Takahashi, K., Shimane, M., Ono, Y., \& Hattori, Y. (2013). Testing the Zimbardo Time Perspective Inventory: Japanese validation study. In M. P. Paixão, J. T. Da Silva, V. Ortuño, \& P. Cordeiro (Eds.), International Studies in Time Perspective (pp. 233-240). Imprensa da Universidade de Coimbra. https://doi.org/10.14195/978-989-26-0775-7_25

Tett, R. P., \& Meyer, J. P. (2006). Job satisfaction, organizational commitment, turnover intention, and turnover: Path analyses based on meta-analytic findings. Personnel Psychology, 46(2), 259-293. https://doi.org/10.1111/j.1744-6570.1993.tb00874.x

The Australian Psychological Society. (2011). Illuminations: Special edition on resilience in organisation.

Yu, M., \& Lee, H. (2018). Impact of resilience and job involvement on turnover intention of new graduate nurses using structural equation modeling. Japan Journal of Nursing Science, 15(4), 351-362. https://doi.org/10.1111/jjns.12210

Zimbardo, P. G., \& Boyd, J. N. (2015). Putting time in perspective: A valid, reliable individual-differences metric. Time Perspective Theory; Review, Research and Application: Essays in Honor of Philip G. Zimbardo. https://doi.org/10.1007/978-3-319-07368-2_2

Zopiatis, A., Constanti, P., \& Theocharous, A. L. (2014). Job involvement, commitment, satisfaction and turnover: Evidence from hotel employees in Cyprus. Tourism Management, 41, 129-140. https://doi.org/10.1016/J.TOURMAN.2013.09.013 
This page intentionally left blank. 